\title{
Relationship Between Capital Structure and Profitability, Evidence From Listed Energy and Petroleum Companies Listed in Nairobi Securities Exchange
}

\author{
Peter Njagi Kirmi \\ Department of Business Administration, Chuka University, Chuka, Kenya
}

\section{Email address:}

Pnjagi06@gmail.com

\section{To cite this article:}

Peter Njagi Kirmi. Relationship Between Capital Structure and Profitability, Evidence From Listed Energy and Petroleum Companies Listed in Nairobi Securities Exchange. Journal of Investment and Management. Vol. 6, No. 5, 2017, pp. 97-102. doi: 10.11648/j.jim.20170605.11

Received: October 9, 2017; Accepted: December 9, 2017; Published: January 10, 2018

\begin{abstract}
Capital structure is the mix of debt and equity that the firm uses in its operation. Managers utilize most of their substantial time in attempting to find the perfect capital structure in terms of risk/reward payoff for shareholders. This is true for both large and small companies trying to strategize on how much of equity and debt to be used without putting the business at risk. The main objective of this study was to determine the relationship between capital Structure and profitability of listed energy and petroleum companies in Kenya by establishing the relationship between long-term and short-term debts with profitability and its effects. Descriptive and causal research designs were used. The study target population was four energy and petroleum companies listed in NSE that operates in Kenya. A census all the 4 energy and petroleum companies listed in the Nairobi securities exchange was used. Secondary data used for data analysis was obtained from the companies financial statements for a period of five years from 2012 to 2016. Data analysis was done using inferential statistics using SPSS. The study established a strong positive relationship between short term debt and ROA and an average negative relationship between Long term debts and ROA and a weak positive relationship between total debt and ROA. Both the short term and long term debts were found to have no significant effect on ROA at 5\% level of significance.
\end{abstract}

Keywords: Capital Structure, Long-Term Debt, Short-Term Debt, Return on Assets, Profitability

\section{Introduction}

\subsection{Background of Study}

Capital structure influence not only the return a company earns for its shareholders, but also influence whether or not a firm survives in a recession or depression states of the economy. Capital structure is the percentage of capital at work in a business by type. It can either take the form of Equity Capital or Debt capital (Joshua, 2017) [9].

According to Abor (2005) [1], capital structure is defined as the mix of debt and equity that the firm uses in its operation, a mixture of different securities such as lease financing, use warrants, issue convertible bonds, forward contracts or issue of bond. Mohammad and Jaafer (2012) [12] noted that firms can use either debt or equity capital to finance their assets. In the case where interest was not tax deductible, firms' owners would be indifferent as to whether they use debt or equity, and where interest was tax deductible; they would maximize the value of their firms by using $100 \%$ debt financing. Use of debt in capital structure of the firm leads to agency costs that arise as a result of the relationships between shareholders and managers, and those between debt holders and shareholders. Equity Capital refers to money put up and owned by the shareholders. This consist of contributed capital, which is the money originally invested in the business in exchange for shares of stock or ownership and retained earnings, which represents profits from past years that have been kept by the company and used to strengthen the balance sheet or fund growth, acquisitions, or expansion. The debt capital in a company's capital structure is the borrowed money that is at work in the business such as bonds, loans, debentures and commercial 
papers. Successful organizations in the world base their base their capital structure on the cost of capital. By ensuring that the weighted average cost of capital is low, the firm gains through the results of increased returns. Most managers utilize most of their substantial time in attempting to find the perfect capital structure in terms if risk/reward payoff for shareholders. This is true for both large and small companies trying to strategize on how much of equity and debt to be used without putting the business at risk.

A study Mohammad and Jaafer (2012) [12] on effect of capital structure on profitability of the industrial companies listed on Amman Stock Exchange found that the capital structure decision is crucial for any business organization because of the need to maximize returns to various organizational constituencies, and also because of the impact such a decision has on an organization's ability to deal with its competitive environment. An appropriate mix of capital structure should be adopted in order to increase profitability.

\subsection{Statement of the Problem}

The success of energy and petroleum companies in Kenya for the last decade has been attributed to sound and effective governance. The companies had seen improved profits realized year after year and a lot of expansion has been witnessed. Of these companies, the most improved are those that are listed in the securities exchange operating under stringent rules from the Capital Markets Authority. However continued good performance of the energy and petroleum sector that is evident from the increased expansion across Kenya and the neighboring countries has raised more questions in an economy that is not performing well. Arising from this, the firm's capital structure employed might have facilitated the results of good performance. This issue has been given little attention by researchers in Kenya and thus it is on this basis that the researcher decided to investigate the relationship between capital structure and profitability of quoted energy and petroleum firms in the Nairobi Stock Exchange.

\subsection{Objective of the Study}

The main objective of the study was to determine the relationship between capital Structure and profitability of listed energy and petroleum companies in Kenya. Specifically the study was guided by the following objectives:

i). To establish the relationship between long-term debt to total assets and ROA of listed energy and petroleum firms in Kenya.

ii). To establish the relationship between short-term debt to total assets and ROA of listed energy and petroleum firms in Kenya.

iii). To establish the effect of short term loan on ROA of listed energy and petroleum firms in Kenya.

iv). To establish the effect of long term loan on ROA of listed energy and petroleum firms in Kenya.

\subsection{Hypotheses of the Study}

The study was guided by the following research hypotheses.

i). $\mathrm{H}_{1}$ : There is no relationship between Short-term debt to total assets and ROA.

ii). $\mathrm{HO}_{2}$ : There is no relationship between Long-term debt to total assets and ROA.

iii). $\mathrm{HO}_{3}$ : There is no significant effect between Short-term debt to ROA

iv). $\mathrm{H}_{4}$ : There is no significant effect between long term debt to ROA

\section{Literature Review}

\subsection{Overview of Capital Structure}

Capital structure describes how a corporation finances its assets. A company's capital structure is composed of equity only or both equity and debt. Capital structure involves different sources from which the required long-term capital is collected by the company. This includes shareholders' funds such as equity capital, preference capital, retained earnings as well as borrowed funds such as debentures, bonds and loans. Abor (2005) [1] investigated the relationship between capital structure and profitability of listed firms on the Ghana Stock Exchange and found that a significantly positive relation between the ratio of short-term debt to total assets and ROE and negative relationship between the ratio of long-term debt to total assets and ROE. Gill, et al., (2011) [19] sought to extend Abor's (2005) [1] findings regarding the effect of capital structure on profitability. He examined the effect of capital structure on profitability of the American Service and Manufacturing firms listed in New Yolk Stock exchange where empirical results indicated a positive relationship between short-term debt to total assets and profitability, total debt to total assets and profitability. Majumdar and Sen (2010) [10] noted that organizations often use debt when constructing their capital structure, which helps lower total financing cost. In general, using debt helps keep profits within an organization and increases returns on equity for current owners and helps secure tax savings. Availability of long-term finance allows manufacturing firms to improve their productivity through purchasing of new capital and equipment thus helping to increase its productivity.

Cecchetti and Schoenholtz (2011) [5] studied the effects of debt on firms and concluded that moderate debt level improves welfare and enhances growth but high levels can lead to a decline in growth of the firm. Rainhart and Rogoff (2009) [16] argued that while debt impacted positively to the growth of a firm only when it is within certain levels. When the ratio goes beyond certain levels financial crisis is very likely. The argument is also supported by Stern Stewart and Company which argues that a high level of debt increases the probability of a firm facing financial distress. Over borrowing can lead to bankruptcy and financial ruin. High levels of debt limit the firm from more investments and undertaking new projects that are likely to be profitable 
because of the inability to attract more debt from financial institutions.

\subsection{Theoretical Literature}

Three theories that guided this study were; the Net Income approach (NI), Net Operating Approach, Traditional Theory of capital structure and the Static Trade-Off theory. Under the net income (Nl) approach, the cost of debt and cost of equity are assumed to be independent of the capital structure. The weighted average cost of capital declines and the total value of the firm rise with increased use of leverage. Under the net operating income (NOI) approach, the cost of equity is assumed to increase linearly with leverage. As a result, the weighted average cost of capital remains constant and the total of the firm also remains constant as leverage changed. If the NI approach is to stand, leverage is a significant variable and financing decisions have an important effect on the value of the firm, on the other hand, if the NOI approach is correct, then financing decisions are not of greater concern to financial managers, as it does not matter in the valuation of the firm.

The Traditional Theory of Capital Structure says that a firm's value increases to a certain level of debt capital, after which it tends to remain constant and eventually begins to decrease. According to this view, the value of the firm can be increased or the cost of capital can be reduced by the judicious mix of debt and equity capital. This approach very clearly implies that the cost of capital decreases within the reasonable limit of debt and then increases with leverage. Thus an optimum capital structure exists and occurs when the cost of capital is minimum or the value of the firm is maximum. The cost of capital declines with leverage because debt capital is chipper than equity capital within reasonable, or acceptable, limit of debt. The weighted average cost of capital will decrease with the use of debt.

The static trade-off theory affirms that firms have optimal capital structures, which they determine by trading off the costs against the benefits of the use of debt and equity. One of the benefits of the use of debt is the advantage of a debt tax shield. One of the disadvantages of debt is the cost of potential financial distress, especially when the firm relies on too much debt (Jensen and Meckling, 1976). Already, this leads to a trade-off between the tax benefit and the disadvantage of higher risk of financial distress. But there are more cost and benefits involved with the use of debt and equity.

\section{Methodology}

\subsection{Introduction}

The chapter outlined the research design and methodology that was applied in conducting this study. It covered research design, target population, sample size and sampling design, data collection methods, measurement of variables and model specification and data analysis.

\subsection{Research Design}

The study used descriptive research design and causal research design. Descriptive research design is a scientific method which involves observing and describing the behavior of a subject without influencing it in any way (Martyn, 2017) [11]. Causal research is the investigation of cause-and-effect relationships (Brains, Willnat \& Rich, 2011) [4] and is used when enough information is available for testing cause and effect relationship in a phenomenon. Causal effect occurs when variation in one phenomenon leads to variation in another phenomenon (Bachman, 2007). In this study descriptive research was useful in trying to explain the phenomenon as it is while causal research design was appropriate in determining if a change in one variable under study causes a change to the dependent variable.

\subsection{Population of the Study}

A population is defined as an entire group of individual or objects having common observable characteristic. It refers to the entire group of people, items or things of interest that the researcher wishes to investigate and from which the sample is drawn and studied (Bowerman, 2012) [3]. The study targeted 4 energy and petroleum companies listed in the Nairobi securities exchange that operates in Kenya.

\subsection{Sampling Procedure and Sample Size}

The study used census of the all the 4 energy and petroleum companies listed in Nairobi security exchange operating in Kenya. Census was useful in this study since the population was small thus aiming at reducing the sampling error.

\subsection{Research Instruments}

Data for the study was collected from secondary data from the company's published financial statements for a period of five years using data collection schedule.

\subsection{Data Collection Procedure}

Data collection is the means by which information is obtained from the selected subjects of an investigation or a study. Data collection procedures provide guidelines for the collection of research data and are intended to improve the usefulness and reliability of data to be collected (Nikoletseas, 2014) [14]. Collection of data was done through studying the financial statements of the companies published in their websites for the last five years. Important data was captured in data collection schedules prepared by the researcher.

\subsection{Data Analysis}

Data collected was analyzed using inferential statistics to meaningfully draw conclusions from data (David, 2005) [7]. Correlation and Regression analysis were used to statistically analyze the relationship between short term and long term debt and profitability.

The regression model used was inform of: 


$$
\mathrm{Y}=\beta \mathrm{o}+\beta_{1} \mathrm{X}_{1}+\beta_{2} \mathrm{X}_{2}+e
$$

Where

$\mathrm{Y}=$ profitability measured by ROA.

$\mathrm{X}_{1}=$ Long-term debt to total assets

$\mathrm{X}_{2}=$ Short-term debt to total assets

$\beta o=$ Intercept which indicates profitability of energy and petroleum companies in absence of debt finance.

$\beta_{1} \& \beta_{2}=$ coefficients of short-term loan to total assets and long-term loan to total assets respectively.

$\mathrm{e}=$ error term which is normally distributed with a mean of zero and a variance of 1 .

\subsection{Diagnostic Tests}

Diagnostic tests such as normality, multicollinearity, auto correlation and heteroskedasticity was carried out to ascertain whether the assumptions of the ordinary least squire holds. Data analysis was facilitated by using statistical package for social sciences (SPSS). T-test was used to test hypothesis at $5 \%$ level of significance.

\section{Results and Discussion}

\subsection{Correlation Analysis}

Pearson correlation coefficient ( $\mathrm{r}$ ) was used to determine the degree of strength and direction of linear relationship among the variables. Linearity increases the predictive power of the model and the validity of the estimated coefficients. A correlation of $r> \pm 0.7$ implies that the variables are strongly related either positively or negatively. The study sought to determine correlation between the variables in order to determine the strength and direction of the relationship. A summary of the correlation coefficients for all the variables is shown in Table 1.

Table 1. Correlation results.

\begin{tabular}{llllll}
\hline Control Variables & ST/TA & LT/TA & TD/TA & ROA \\
\hline \multirow{4}{*}{ ROA } & Correlation & .674 & -.672 & .178 & 1.000 \\
& Significance (2-tailed) & .326 & .328 & .822 &. \\
& Df & 2 & 2 & 2 & 0 \\
\hline
\end{tabular}

Results in Table 1 indicate a strong positive relationship between shot-term debt to total assets and ROA of energy and petroleum firms listed in Nairobi Securities Exchange with a Pearson correlation coefficient of 0.674 . This implies that the higher the ratio of short-term debt to Total assets the higher the ROA realized by the firms. The relationship between long-term debt to total assets and ROA is negative correlation with a Pearson coefficient of -0.672 . This implies that when long-term debt is increased, ROA decreases. These finding are in agreement with findings of Abor (2005) [1] who examined the effect of capital structure on the corporate profitability of listed firms in Ghana and found a positive relationship between short-term debt ratio and profitability and a negative relationship between long term- debt ratio and profitability.

Table 1 also indicates a weak positive relationship between total debt to total assets and ROA with a Pearson correlation coefficient of 0.178 . This implies that when the ratio of debt to total assets is increased, ROA of energy and petroleum firms listed in Nairobi Securities exchange increase increases. These finding agrees with the study by Charles and Peter (2015) [6] on the effect of debt financing on the profitability of SMES in Accra Metropolis, which found a positive association between total debt ratio and profitability. However the findings contradict Gleason et al. (2000) [20] in their study of Interrelationship between Culture, Capital Structure, and Performance who examined the relationship between performance and leverage by using return on asset. The finding indicated that total debt has a significant, negative influence of performance.

\subsection{Regression Analysis Results}

The study sought to determine the relationship between capital structure and profitability of energy and petroleum companies listed in Nairobi securities exchange that operates in Kenya. The variables accessed were short term debt to total assets and long-term debt to total assets while the dependent variable was profitability measured by ROA. To analyze this, a multiple linear regression model was developed and adopted in the study. The results of the strength of the relationship between predictor variables and ROA and the significance of the relationship are presented in table 2 and 3.

Table 2. Regression analysis results.

\begin{tabular}{lllll}
\hline Model Summary $^{\mathbf{b}}$ & & & & \\
\hline Model & $\mathrm{R}$ & R Square & Adjusted R Square & Std. Error of the Estimate \\
1 & $.721^{\mathrm{a}}$ & .520 & -.439 & .0384859 \\
\hline
\end{tabular}

a. Predictors: (Constant), LT/TA, ST/TA

b. Dependent Variable: ROA

Table 2 shows the correlation coefficient $(\mathrm{R})$ was 0.721 . This indicates a strong positive relationship between debt and ROA of energy and petroleum companies listed in Nairobi Securities Exchange. The $\mathrm{R}^{2}$ was 0.52 implying that $52 \%$ of the variation in the model is accounted for by the changes in Short-term and long-term debts while $48 \%$ was explained by other factors outside the model.
From table 3, the value of the intercept was 0.050 . This indicates the performance of the energy and petroleum companies in terms of ROA in absence of Short-term and long-term debts. The coefficient of short term debt to total assets was 0.085 and that of long-term debts to total assets was -0.101 hence the model is therefore presented as follows:- 
Table 3. Individual significance of the model.

\begin{tabular}{lllllll}
\hline \multirow{2}{*}{ Model } & & \multicolumn{2}{l}{ Unstandardized Coefficients } & Standardized Coefficients & \multirow{2}{*}{ T } & Sig. \\
\cline { 3 - 6 } & & B & Std. Error & Beta & .762 & .586 \\
\multirow{2}{*}{1} & (Constant) & .050 & .066 & .390 & .380 & .769 \\
& ST/TA & .085 & .223 & -.383 & -.373 & .773 \\
\hline
\end{tabular}

$$
\mathrm{Y}=0.050+0.085 \mathrm{X}_{1}-0.101 \mathrm{X}_{2}
$$

Where $\mathrm{Y}$ is profitability measured by ROA and $\mathrm{X}_{1}, \mathrm{X}_{2}$ is the value of short term-debt and Long-term debt to total assets respectively.

\subsection{Effect of Short Term Debt on ROA}

From table 3, the coefficients of short term debt to total assets is 0.085 with a P-Value of $0.769>0.05$. This implies that a unit increase in short term debt to total assets will result into 0.085 unit increase in ROA of energy and petroleum companies listed in Nairobi Securities exchange. However the result imply that short term debt to total assets does not have a significant effect on ROA of energy and petroleum firms listed in Nairobi securities Exchange, hence the null hypothesis that short term debt to total assets does not have a significant effect on ROA was accepted at 5\% level of significance. These findings imply that even though an increase in short term debt in energy and petroleum firms listed in Nairobi Securities exchange lead to $8.5 \%$ unit increase in profitability, a large portion of the profitability increase originates from other factors outside the model. The findings support finding by Tiffany (2015) [18] and Nitin (2015) [15] who argued that short term loans are advantageous to a firm since not affected by fluctuations of interest rates that increases the cost thus lowering the firm's profitability. However the results contradicts Charles and Peter (2015) [6] argument that short term loan reported a negative effect on return on asset and that an increase in short term loan would results in decrease in return on asset. The study findings agrees with the theory of net income approach which advocates the use of external debt to increase the value of the firm since it has been established that by increasing the short term debt in the capital structure, results to a slight increase in profitability of the firms.

\subsection{Effect of Long Term Debt on ROA}

From table 3 also, the coefficients of long-term debt to total assets is -0.101 with a P-Value of $0.773>0.05$. This implies that a unit increase in long-term debt to total assets will result into 0.101 unit decrease in ROA of energy and petroleum companies listed in Nairobi Securities exchange. However the result imply that long-term debt to total assets does not have a significant effect on ROA of energy and petroleum firms listed in Nairobi securities Exchange, hence the null hypothesis that long-term debt to total assets does not have a significant effect on ROA was accepted at 5\% level of significance. The results indicate that when ratio of long term debt to total assets is increased, there will be a decrease in profitability, however the results shows that the decrease is insignificant. The effect was insignificant as clearly shown by p-value of 0.773 which is more than 0.05 hence this finding confirms Myers (1997) [13] and Charles and Peter (2015) [6] who argued that a firm's reliance on long term loan leads to greater distortions and increases the firm's financing costs thus reducing its profits. Also the study concurs with results of study by Isabwa and Albert (2015) [8] on effect of long-term loan on firm's performance in Kenya, who established that Long term loan negatively, affects ROA.

\section{Conclusion}

The study aimed at establishing the relationship between debt and profitability of energy and petroleum firms listed in Nairobi Securities exchange. The study established a weak positive relationship between Total Debt and ROA. This implied that an increase in debt lead to an increase in ROA of energy and petroleum firms listed in Nairobi Securities exchange.

On the relationship between Short term debt to total assets and ROA, the study established a strong positive relationship between shot-term debt to total assets and ROA of energy and petroleum firms listed in Nairobi Securities Exchange. This implied that the higher the ratio of short-term debt to Total assets the higher the ROA realized by the firms.

On the relationship between long-term debt to total assets and ROA the study established an average negative correlation. This implied that when long-term debt is increased, ROA decreases.

On the Effect of short-term debt to total assets on ROA of energy and petroleum firms listed in Nairobi Securities exchange, the study established an insignificant effect of Short-term debt to ROA at 5\% level of significance even though the results found that an increase in short term debt leads to an increase in ROA.

Long-term debt on the other hand was found to have also an insignificant effect on ROA at 5\% level of significance. However an increase in long-term debt was found to lead to a decrease in ROA of energy and petroleum firms listed in Nairobi securities Exchange.

The study concluded that both long-term debt and short term debt affect a firm's profitability positively or negatively. Specifically, the study concluded that Long term loan negatively affects firm Profitability and Short term loan positively affect the firms profitability as measured by ROA even though not statistically significant. As the proportion of long term debt used in a firms capital structure increases its financial profitability decreases and as the proportion of short-term loan in the capital structure increases its profitability increases. 


\section{References}

[1] Abor, J. (2005) "The effect of capital structure on profitability: an empirical analysis of listed firms in Ghana", The Journal of Risk Finance, Vol. 6 Issue: 5, pp.438-445, doi: $10.1108 / 15265940510633505$.

[2] Bachman, R. (2007). The Practice of Research in Criminology and Criminal Justice, Causation and Research Designs. 3rd ed. Thousand Oaks, CA: Pine Forge Press.

[3] Boweman, O. P. (2012) Essentials of business statistics. $3^{\text {nd }}$ edition.

[4] Brains, C., Willnat, L., Manheim, J., \& Rich, R. (2011). Empirical Political Analysis 8th edition. Boston, MA: Longman.

[5] Cecchetti, S. \& Schoenholtz, K. (2011): Money, banking and financial markets, third edition, New York, McGraw-Hill.

[6] Charles, A. and Peter, L. A. The Effect of Debt Financing on the Profitability of SMEs in Accra Metropolis. Adrri Journal of Arts And Social Sciences. ISSN: 2343-6891 ISSN-L: 23436891VOL. 13, No. 2 (2), May, 2015.

[7] David, A. F. (2005). Statistical Models: Theory and Practice, Cambridge University Press.

[8] Isabwa, K. H and Albert, C.. (2015). The effect of long term loan on firms performance in Kenya. A survey of selected sugar manufacturing firms. Global Journal of advanced research, vol-2, issue 6, pp 1019-1024. ISSN: 2394-5788.

[9] Joshua, K. (2017). An Introduction to Capital Structure. Why Capital Structure Matters to Your Investments, Retrieved from https://www.thebalance.com/an-introduction-to-capitalstructure-357496.html.
[10] Majumdar, S. K., \& Sen, K. (2010). Corporate Borrowing and Profitability in India. Managerial and Decision Economics.

[11] Martyn Shuttleworth, 2017 Descriptive Research Design Retrieved from https://explorable.com/users/martyn https:/explorable.com/descriptive-research-design.

[12] Mohammad, F. S \& Jaafer, M. (2012) The Relationship between Capital Structure and Profitability. International Journal of Business and Social Science Vol. 3 No. 16 SI August 2012, ISSN 2219-1933.

[13] Myers, S. C. (1984). The Capital Structure Puzzle.. The Journal of Finance. 39 (3), 575-592.

[14] Nikoletseas, M. M. (2014). "Statistics: Concepts and Examples.” ISBN 978-1500815684.

[15] Nitin B. (2015). Loan repayment decisions.

[16] Rainhart \& Rogoff (2009). The Aftermath of Financial Crises, Working Paper No. 14656.

[17] Siddharth Kalla (2017) Correlational study. Retrieved at https://explorable.com/correlational-study $161.7 \mathrm{~K}$ reads 1 Comment.

[18] Tiffany, C. W. (2015). The Advantages of Long-Term Debt Financing. Demand Media. Retrieved from http://smallbusiness.chron.com/advantages-longterm-debtfinancing-60857.html

[19] Gill, Amarjit. (2011). The effects of capital structure on profitability: Evidence from United States. International Journal of Management. 28. 3-15.

[20] Kimberly C. Gleason (2000). The Interrelationship between Culture, Capital Structure, and Performance: Evidence from European Retailers. Journal of Business Research 50, 185191. 